\title{
Mais mente na pesquisa cerebral! O legado de Josef Breuer
}

\author{
Gildo Magalhães ${ }^{1}$ \\ Professor Titular do Departamento de História \\ Diretor do Centro de História da Ciência - Universidade de São Paulo \\ gildomsantos@hotmail.com
}

Como citar este artigo: Magalhães, Gildo. "Mais mente na pesquisa cerebral! O legado de Josef Breuer”, Intelligere, Revista de História Intelectual, $\mathrm{n}^{\circ}$ 9, pp. 270-311. 2020. Disponível em <http://revistas.usp.br/revistaintelligere>. Acesso em dd/mm/aaaa-

\section{Sobre o Autor}

Jonathan Benjamin Tennenbaum nasceu em Chicago, em 1950 e se doutorou em 1973 em matemática na Universidade da Califórnia em San Diego. Após ser instrutor na Universidade de Odense e professor assistente na Universidade de Copenhague, na década de 1980 mudou-se para a Alemanha e foi de 1980 até 2006 diretor da "Fundação para Energia de Fusão" na Europa, se dedicando a assuntos avançados de ciência, tecnologia e desenvolvimento econômico, bem como à história e filosofia da ciência e à divulgação científica para jovens. Entre seus interesses especiais organizou seminários internacionais sobre biofísica e fez pesquisas com D. Doubochinsky sobre quantização macroscópica em pêndulos magnéticos com acoplamento não linear. Nesse período, publicou diversos artigos e foi consultor em projetos na Rússia e na China, além de ter participado de pesquisa com a Sociedade Americana de Matemática para a publicação de textos inéditos de Bernhard Riemann, um dos mais influentes cientistas do século XIX.

\footnotetext{
${ }^{1}$ Gildo Magalhães é Professor Titular do Departamento de História da Faculdade de Filosofia, Letras e Ciências Humanas da Universidade de São Paulo, professor de História colaborador do ISCTE - Instituto Universitário de Lisboa) e da Universidade de Lisboa (Centro de Filosofia da Ciência). Dirige o Centro Interunidades de História da Ciência da Universidade de São Paulo.
} 
Tendo participado de algumas controvérsias notórias na história recente da ciência, Jonathan Tennenbaum esteve no Brasil para dar cursos de história e conceitos de energia nuclear, inclusive no Instituto de Pesquisas Energéticas e Nucleares, no campus da Universidade de São Paulo. Destacou-se por sua posição sempre entusiasmada e otimista sobre a energia de fusão nuclear, mas enfatizando a etapa intermediária atual da fissão nuclear. Também fez conferências no Centro de História da Ciência da Universidade de São Paulo e dentro do projeto temático "Eletromemória” (FAPESP).

No Brasil, além de artigos, foi publicado em 2000 seu livro Energia Nuclear - Uma Tecnologia Feminina" (2000), que contém uma ampla e exemplar história das descobertas relativas à radioatividade e ao uso da energia de fissão nuclear nos séculos XIX e XX, desvelando o surpreendente papel das mulheres cientistas nesse campo. Este e os seguintes livros seus foram traduzidos por Gildo Magalhães e também publicados em português: A Economia dos Isótopos (2007), Energia nuclear: dínamo da reconstrução econômica mundial (2010) e A economia física do desenvolvimento nacional (2016).

Atualmente, além de sua atividade como consultor e escritor, Jonathan Tennenbaum atua como pianista e organizador de eventos musicais.

\section{Sobre o texto}

No presente ensaio, Jonathan Tennenbaum se debruça sobre a questão já clássica da possibilidade de haver inteligência artificial, no sentido de algo que se equivalha ou substitua a mente humana. Para isso, examina algumas controvérsias e paradoxos da atual ciência cognitiva, comparando-a com a visão reducionista da vida à física e química. Em seguida, recorre à história um tanto esquecida de Josef Breuer, médico vienense que se associou a Sigmund Freud no início da história da psicanálise. Trata-se do caso de "Ana O.", um famoso estudo de histeria que forneceu as chaves para o desenvolvimento do método psicanalítico, que se tornaria cada vez 
mais divulgado em seguida. Ao longo do texto, pode-se observar o amplo conhecimento que o autor tem da história e filosofia de ideias científicas.

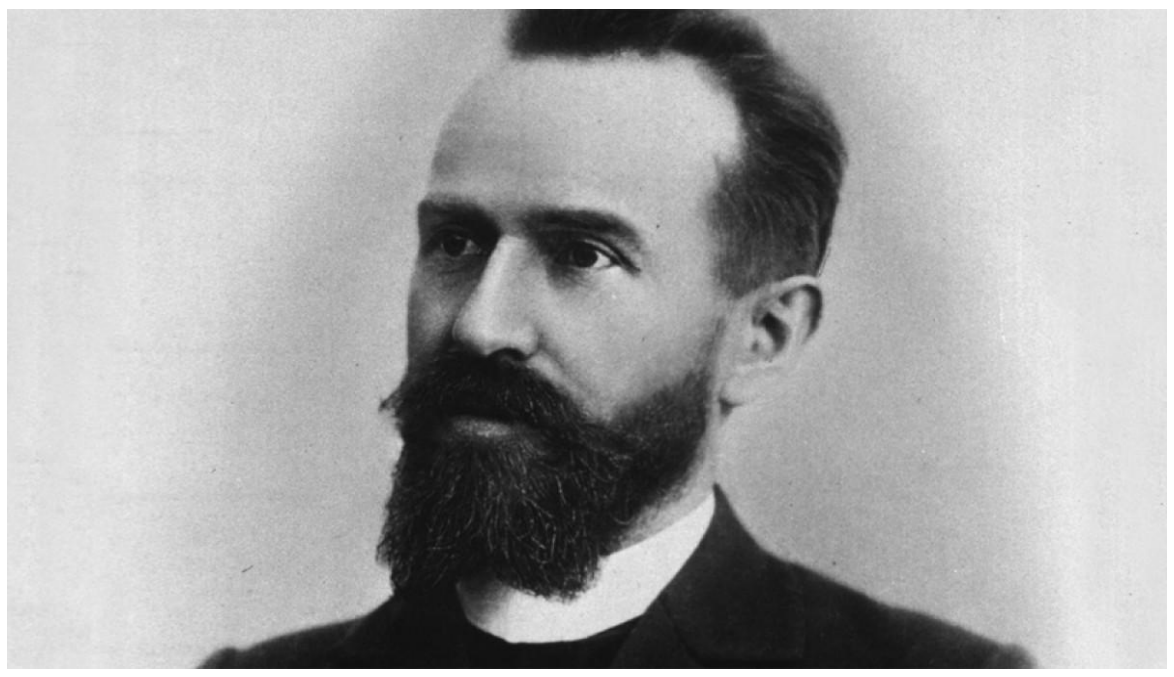

Josef Breuer (1842-1925) - Fonte: Wikipedia

A presente tradução é de autoria de Gildo Magalhães, a partir do original "Mehr Geist in die Hirnforschung! Das Vermächtnis von Josef Breuer", publicado em Berlim (Verlag Edmund Steinschulte, 2007). O texto original está disponível em https://www.spree-athenev.de/bibliothek/mehrgeistindiehirnforschung.html

\section{TRADUÇÃO}

Ultimamente a pesquisa do cérebro goza de crescente atenção, tanto do público quanto do mundo acadêmico. É bom que as pessoas se interessem cada vez mais pelas funções e usos desse órgão fundamental. Contudo, a pesquisa do cérebro e sua irmã, a ciência da psicologia, têm de lutar com paradoxos básicos e dificuldades metodológicas que repousam inteiramente na natureza auto-reflexiva de seu objeto. Quem deseja pesquisar a mente humana e o cérebro coloca ao mesmo tempo seu próprio pensar à prova! A qualidade da pesquisa liga-se então de forma muito estreita com o ambiente cultural do pesquisador.

Há dois problemas básicos com os quais se defronta a qualidade mental do pesquisador cerebral. Em primeiro lugar, a questão da relação 
entre mente e cérebro - entre as atividades da mente, como vivenciadas "de dentro" ou junto à própria mente, e os processos físicos no cérebro que, como parece, constituem o substrato material indispensável do pensamento. Os elementos das atividades mentais e dos processos cerebrais físicos parecem, no entanto, totalmente não homogêneos: de um lado as imagens, ideias, desejos, intenções, livre arbítrio; de outro lado, os impulsos elétricos, processos químicos, as leis insensíveis da física. A atividade mental e a atividade cerebral estão acopladas ao máximo, no entanto não se encontra no mundo duas coisas que sejam tão completamente diferentes.

Um segundo grande paradoxo, cuja abrangência é menos reconhecida, se esconde na pergunta: o que faz de fato o cérebro humano? Uma resposta adequada a essa pergunta, que deveria estar bem no primórdio da pesquisa cerebral, exige consideravelmente mais reflexão do que a maioria dos pesquisadores hoje consegue realizar. Pois o marco principal da mente humana é a capacidade de continuar se desenvolvendo, uma propriedade que de alguma forma deve também ter se alojado no cérebro enquanto órgão biológico. Em contraposição o pesquisador só consegue pensar concretamente com sua própria mente, com seu próprio cérebro! Como ele pode se impedir de transportar a limitação de sua própria capacidade mental, que subjaz em cada mortal, para o objeto da pesquisa?

Um olhar para o debate científico atual mostra que a dificuldade não existe apenas teoricamente. Quem, por exemplo, de sua perspectiva científica perde processos mentais verdadeiramente criativos e pensa apenas mecanicamente, terá dificuldade em imaginar o funcionamento do cérebro e da mente para além do mecanicismo. Quem, pelo contrário, renuncia ao rigor frio das leis da física e procura refúgio em uma representação puramente ideal ou até esotérica, não consegue vencer o dualismo paralisante no próprio pensamento e não conseguirá responder com sentido à pergunta sobre a relação entre as atividades da mente e as do cérebro.

Os paradoxos mencionados existem desde os primórdios da ciência, eles são de certa maneira necessários e continuarão a subsistir de alguma forma. O que muda com o correr do tempo é o tipo de tratamento desses 
paradoxos. Justamente nisso se refletem os progressos do conhecimento, na medida em que ultrapassam o puramente técnico e mergulham mais profundamente. Como fica hoje então a pesquisa do cérebro, quando o que foi referido se torna o padrão? Há certamente um desenvolvimento técnico de tirar o fôlego que, desde processos modernos de imagem até os métodos mais refinados da biologia molecular, dá ao pesquisador possibilidades insuspeitadas de pesquisar o que se passa fisicamente no cérebro. Em comparação com esse progresso técnico fantástico, o progresso conceitual é menos do que modesto.

O problema mostra-se não menor na paralisia de todo pesquisador que se utiliza praticamente apenas de metáforas e analogias do campo dos sistemas de processamento de dados para a compreensão das atividades do cérebro. Atrevemo-nos até a afirmar que com o uso de esquemas conceituais simplistas da teoria da informação e da chamada "revolução cognitiva" - que a meu ver não merece esse nome - a pesquisa moderna do cérebro conceitualmente regride bem abaixo do nível de cem anos atrás. Por exemplo, em um "Manifesto de onze neurocientistas notáveis" que foi publicado em 2004 na revista Gebirn und Geist, fala-se até das fronteiras dos "conceitos atuais da informática e da inteligência artificial", mas no mesmo texto deparamo-nos com formas de expressão típicas tais como:

"Queremos descobrir como circuitos de centenas ou milhares de neurônios codificam, avaliam a informação no conjunto global do cérebro ..."

Devemos tomar essa afirmação ao pé da letra? Os neurônios são realmente apenas "interruptores"? Ou deveriam finalmente - como o manifesto coloca em perspectiva - valer plenamente como pequenos seres vivos? Caso afirmativo, quando não os consideramos equivalentes a simples circuitos eletrônicos que trocam "bytes", então coloca-se de imediato a pergunta seguinte: que "informações” são essas, que se devem codificar e avaliar? No que são transformadas essas informações? Olhemos para um belo rosto, ou ouçamos uma peça musical de Bach. As impressões dos sentidos agem sobre nós, nós recebemos uma determinada impressão global, 
somos transportados para uma determinada atmosfera emocional. O conceito de "informação" é mesmo apropriado?

O motivo da paralisia conceitual não está em nossa desconsideração pela pesquisa cerebral ou pela psicologia em si, mas num enfraquecimento geral da influência daquela cultura humanista que por séculos levou a grandes resultados nas ciências naturais e humanas. Sua especificidade é que em cada indivíduo humano ela desperta e desenvolve os processos mentais criativos, que levaram ao aumento visível das maiores descobertas nas ciências naturais, aos trabalhos de arte e às ações morais na história humana. Isso não significa naturalmente que todo mundo que desfrute de uma educação clássica, no sentido de Humboldt, se torne automaticamente um grande gênio. A cultura clássica e a educação podem, porém, desenvolver em cada pessoa uma consciência de que o homem é primeiramente um ser mental, que a mente humana está além dos objetos da percepção sensorial e também percebe outros objetos - as ideias - e consegue passo a passo na busca conjunta pela verdade descobrir as ideias e os princípios superiores, de acordo com os quais o mundo visível está organizado. Isso pode nos transportar junto com a arte clássica para uma certa atmosfera alegre e gratificante.

O que tem a ver a pesquisa do cérebro com uma atmosfera alegre? Como essa pergunta não é de forma alguma banal, mas traz em si algo muito frutífero, quero aqui invocar um exemplo tirado da História. Trata-se da pesquisa mental de Josef Brener (1842-1925) - o genial médico, fisiólogo e sábio universal, que Sigmund Freud chamava de verdadeiro descobridor da psicanálise. Um brilhante representante da intelectualidade judia do seu tempo, Breuer estava inteiramente na tradição humboldtiana da unidade entre ciências humanas e naturais. Nos debates científicos da época entre espírito e matéria ele representava, juntamente com Gustav Fechner e Ewald Hering, um ponto de vista "monista", que o conduziu a importantes descobertas na psicologia, assim como na fisiologia dos órgãos dos sentidos e do sistema nervoso. Esse ponto de vista permanece mais atual do que nunca para a pesquisa do cérebro. 
A seguir, quero deixar falar principalmente Breuer e seus companheiros espirituais, Fechner e Hering, e mostrar como se portavam perante os paradoxos fundamentais da pesquisa do cérebro e da psicologia. Será enfatizada a atmosfera de que falamos, e com ela uma clareza empolgante para lidar com ideias, de que hoje se poderia aprender muito. A última palavra dou para a famosa paciente de Breuer, Bertha Pappenheim, que depois de sua cura se tornou uma das mais luminosas personalidades de seu tempo. Em poucas linhas ela expressa o que a ciência atual nunca deveria deixar de lado.

\section{Quem foi Josef Breuer?}

Primeiramente uma curta biografia de Josef Breuer. Para maiores detalhes sobre a pessoa de Breuer recomendo o livro, bem útil, de Albrecht Hirschmüller, Fisiologia e psicanálise na vida e obra de Josef Brener (1978). Josef Breuer nasceu em 15 de janeiro de 1842 em Viena, onde seu pai era há um bom tempo professor de religião na comunidade judaica. Com a idade de oito anos ele foi para um "ginásio acadêmico", uma instituição bem tradicional, que seguia o princípio da escola humanista e ao mesmo tempo enfatizava especialmente as matérias de ciências naturais. Oito anos depois, Breuer seguiu para a Universidade de Viena, onde nos primeiros anos recebeu uma educação amplamente filosófica e científica. A partir de1859/60 ele começou ali uma especialização em medicina, que concluiu em 1864. Entre seus professores se encontravam alguns dos melhores médicos e pesquisadores de sua época - dentre os quais Carl Rokitansky (chamado por Virchow de "Lineu da patologia"); o fundador da fisiologia na Áustria e defensor do chamado "movimento biofísico", Ernst Brücke; o fisiólogo e clínico Johann Oppolzer sem falar do genial fisiólogo e filósofo natural Ewald Hering, do qual logo ouviremos mais.

Em junho de 1864, Breuer se titulou como doutor em medicina e se tornou assistente de Oppolzer na Faculdade de Medicina. Posteriormente, após algumas candidaturas a professor sem sucesso, ele se retirou da vida 
acadêmica. Estabeleceu-se como médico praticante em 1871 e se tornou rapidamente um dos mais conhecidos e apreciados médicos da cidade. Por meio de sua prática conheceu muitas personalidades famosas de Viena. Entre seus pacientes se encontravam diversos artistas, compositores, escritores e cientistas; de muitos, se tornou amigo pessoal. Breuer acompanhou, dentre outros, o compositor Johannes Brahms em seus últimos anos de vida.

O próprio Breuer se tornou uma das figuras mais importantes da vida intelectual e cultural do seu tempo. Seu biógrafo Alfred Hirschmüller explica o porquê: "no campo da ciência natural Breuer era excepcionalmente bem instruído. Bons conhecimentos dos principais desenvolvimentos da física, química, biologia, cosmologia e assim por diante eram de se esperar de um médico na época de Breuer ... Menos comum era um conhecimento tão profundo da literatura filosófica como a mostrada por Breuer. De Empédocles a Schopenhauer, de Espinosa e Leibniz a Poincaré e Mach, todos esses pensadores ele conseguia compreender ... Em suas cartas ele discutia o valor da formação clássica e do conhecimento de história, a evolução das diferentes formas do Estado, ... citava o Talmude e a Bíblia, os paralelos entre budismo e cristianismo e os fundamentos da teologia paulina."

Em sua biografia sobre Breuer, observa seu sobrinho Hans-Horst Meyer: "Quem teve a oportunidade de entrar numa conversa e troca de idéias com J. Breuer, conseguia não só descobrir sua erudição variada e fundamentada em geral, mas também observar maravilhado em que medida espantosa o que havia sido lido e refletido era sempre tornado presente com toda clareza e transparência." Ademais, Breuer era uma pessoa extraordinariamente simpática - "(sua atenção e suavidade) lhe permitiam mesmo em tempos sombrios uma tranquilidade sempre calma, muita vez alegre, aquele 'otimismo, que só é possível, quando se o deseja', como ele uma vez disse, e um temperamento muito cheio de vida, em geral grato e feliz." 
Em paralelo com sua prática de medicina, Breuer continuava a fazer pesquisas científicas na sua vida privada e obteve na fisiologia uma série de resultados importantes, que em parte estão até hoje associados com seu nome. Dentre eles se contam:

- A demonstração decisiva de que a febre não é desencadeada através do sistema nervoso, mas é humoral, isto é, disseminada por determinadas substâncias no corpo, com o que se resolveu um antigo debate.

- A descoberta de um importante mecanismo de regulação da respiração, o chamado reflexo de Breuer-Hering.

- Esforços pioneiros na pesquisa do papel desempenhado pelos canais auditivos e pelo sistema de ossículos auditivos para o sentido do equilíbrio e do reconhecimento do movimento.

Do lado científico, Breuer ficou em especial sob a influência abrangente de Ewald Hering (1834-1918), um dos principais fisiólogos e pesquisadores do cérebro da sua época. Hering pertenceu à "segunda geração" da famosa escola de fisiologia e psicologia de Leipzig. A "escola de Leipzig" foi em geral de importância decisiva para todo o campo científico de Breuer. Ela foi fundada pelos famosos irmãos Weber - Ernst Heinrich (1795-1878), Eduard Friedrich (1806-1871) e Wilhelm Eduard (1804-1891) - juntamente com o legendário filósofo, fisiólogo e fundador da "psicofísica", Gustav Theodor Fechner (1801-1887). Breuer estava próximo das posições filosóficas de Fechner em muitos pontos, de acordo com suas próprias afirmações.

A escola de Leipzig estava estreitamente ligada aos círculos de Göttingen em torno do matemático Carl Friedrich Gauss (1777-1844), de Johann Friedrich Herbart (1776-1841) e mais tarde, de Bernhard Riemann (1826-1866). Wilhelm Weber, o pai da eletrodinâmica e um dos maiores físicos de todos os tempos, atuava como membro de ligação. Wilhelm Weber foi em sua época de Göttingen o amigo pessoal mais próximo de Gauss; juntamente com este, ele dirigiu a chamada "Sociedade Magnética" e 
construiu o primeiro telégrafo elétrico. Depois que Wilhelm em 1837 precisou se mudar para Leipzig, por ser um dos "Sete de Göttingen" que protestaram contra o governo, ele desenvolveu um trabalho conjunto mais estreito com os demais irmãos Weber, que deram um enorme impulso ao desenvolvimento da psicologia, especialmente da eletrofisiologia. Acima de tudo, abriu-se pela primeira vez a possibilidade de um estudo experimental exato da atividade elétrica das células nervosas.

A isso se associou a psicologia. O psicólogo e pedagogo de Göttingen, Johann Friedrich Herbart, fez uma das primeiras e mais influentes tentativas, a partir da monadologia de Leibniz, de desenvolver a psicologia como uma ciência exata. O continuador de Herbart em Göttingen foi o médico e filósofo de Leipzig, Rudolf Hermann Lotze (1817-1881), que se considerava um leibniziano e cujo livro "Microcosmo" gozou de enorme popularidade em sua época. O jovem cientista Riemann, continuador de Gauss, teve aulas com ambos. Os trabalhos revolucionários de Riemann sobre a geometria física, sobre o surgimento no cérebro de "massas mentais", sobre a eletrodinâmica, sobre a constituição dos órgãos dos sentidos e muito mais, só podem ser compreendidos corretamente no contexto do vivo intercâmbio científico com Gauss, com os irmãos Weber, Fechner e outros.

Ewald Hering, que estudou junto com os irmãos Weber e Fechner em Leipzig, contribuiu decisivamente para o desenvolvimento da psicologia, especialmente para a compreensão da percepção visual. Ele se tornou conhecido como o grande opositor de Hermann von Helmholtz, graças a seus pontos de vista sobre o fenômeno da vida e as funções dos órgãos dos sentidos. Em 1865 ele foi para a academia militar de Viena (Academia Joseph), onde Josef Breuer estudou fisiologia com ele. Posteriormente, desenvolveu-se uma fértil cooperação científica entre ambos. 


\section{A histeria como paradoxo na pesquisa cerebral}

No que se segue, não me ocuparei mais com os trabalhos fisiológicos de Breuer, mas quase que unicamente com sua contribuição à psicanálise, embora ela constitua apenas uma pequena fração da sua carreira. Mesmo essa contribuição mostra o modo de pensar de Breuer muito claramente e contém a mais forte exigência para a atual pesquisa cerebral. Pedimos, portanto, compreensão se, a seguir, nós atingimos apenas uma certa profundidade na psicologia, e então na conclusão faremos algumas reflexões sobre o futuro da pesquisa cerebral.

A psicanálise se encontra hoje numa situação paradoxal. Por um lado, fala-se de um novo "diálogo entre pesquisa cerebral e psicanálise", no qual, por exemplo, a existência de processos mentais inconscientes seria confirmada com ajuda de novos processos de imagem. Por outro lado, no entanto, diversos círculos especializados trabalham há anos para afastar os últimos restos de autoridade científica da psicanálise e para finalmente enterrar Sigmund Freud como um "cão morto". Nisso não se pode deixar passar que os trabalhos de desconstrução atingem em primeira linha o edifício teórico da psicanálise, principalmente a teoria sexual de Freud e sua, por vezes, extravagante "metapsicologia". Eles atingem menos os primeiros trabalhos, as primeiras compreensões surpreendentes da natureza dinâmica das enfermidades psíquicas, adquiridas inicialmente por Josef Breuer e depois pelo trabalho conjunto dele com Freud, basicamente nos anos de 1886-1893.

Logo depois da publicação do primeiro trabalho, Estudos sobre a Histeria (1895), interrompeu-se o estreito trabalho conjunto dos dois. Embora se costume atribuir isso ao pensamento de Breuer supostamente contra a ênfase dada por Freud ao elemento sexual na histeria, Albrecht Hirschmüller argumenta de forma muito convincente que a causa real do rompimento deve ser procurada nas diferenças fundamentais com respeito ao método e convicção científicos. 
Que tais diferenças profundas existiram de fato pode ser facilmente demonstrado. Elas têm na verdade a ver com os paradoxos da cabeça, que expusemos no início desse artigo. Basta comparar o Esboço de uma psicologia científica de Freud, escrito no mesmo ano de 1895, com os escritos e cartas de Breuer e os de seu professor Ewald Hering. No Esboço, Freud incorre com veemência nos mesmos erros metodológicos que hoje podemos constatar na pesquisa cerebral. Ele se perde no mais extremado reducionismo, procurando conduzir todas as funções mentais a um tipo de "energética" dos neurônios. O próprio Freud precisou poucos meses depois se restringir numa carta: "Não compreendo mais o estado mental, no qual fundamentei a psicologia." Embora Freud não tenha publicado seu Esboşo (o trabalho só foi lançado muito depois de sua morte), o mesmo impulso solitário e obstinado continua a viger em seu pensamento, principalmente nas partes teóricas de seus trabalhos.

O objeto do trabalho original conjunto de Breuer e Freud é ainda hoje de grande interesse para a pesquisa cerebral. O quadro clássico da histeria (hoje se fala de distúrbios dissociativos e distúrbios de conversão) se estende por diferentes combinações de sintomas psicossomáticos principalmente de caráter neurológico - juntamente com fortes distúrbios neuróticos (emocionais). Muitas vezes os sintomas isolados se parecem tanto com paralisias, anestesias, convulsões, distúrbios visuais, doenças orgânicas reais, que frequentemente causam grande dúvida no médico, se não poderia mesmo haver um distúrbio orgânico não manifesto. É muito importante, principalmente para o leigo, esclarecer se esses danos realmente não estão presentes: o paciente é igualmente uma vítima, ele controla a sintomática tão pouco quanto numa doença orgânica.

Aqui nos movemos numa fronteira fascinante e muito relevante entre a fisiologia e a psicologia, que também tem grande importância para a biologia e a medicina. Ao final deste artigo falarei disso mais detalhadamente. O grande ponto histórico de transição na compreensão e terapia da histeria foi com o tratamento por Breuer de Bertha Pappenheim - conhecida nos Estudos como "Anna O." Para poder avaliar a grandeza das contribuições de Breuer, é preciso recordar que ele não era nenhum 
especialista em doenças psíquicas, mas apenas um médico clínico geral - no entanto com formação e interesses bem incomumente amplos - que, além disso, realizava pesquisas fisiológicas.

\section{A ruptura de Breuer}

O caso de "Anna O" costuma ser exaustivamente descrito, mas raramente o é do ponto de vista do processo de descoberta desencadeado por Breuer, de certa forma num trabalho conjunto com sua paciente. Limito-me aqui apenas a poucos pontos-chave importantes, que deixarei o próprio Breuer relatar. Para tal não utilizarei a famosa história "oficial" da doente, que foi publicada nos Estudos sobre Histeria, mas farei citações a partir de um relato anterior de Breuer para Robert Binswanger, então diretor do famoso sanatório Bellevue, no qual Bertha Pappenheim continuou a ser tratada.

Breuer começa de forma característica, não com frios fatos da medicina, mas dando um quadro geral sensível da paciente, e que exprime um respeito completo pelo seu talento extraordinário e pela força de caráter:

"Bertha Pappenheim, agora com 23 anos, de inteligência elevada; memória excelente, bom gosto surpreendentemente aguçado e intuição perspicaz, por isso as tentativas de enganá-la sempre falham. Intelecto forte, que também poderia ser alimentado, mas que não o foi desde que saiu da escola.

Vida muito monótona, inteiramente restrita à família; procura compensação no amor apaixonado pelo pai, que a mima, e no gozo do talento poético-fantástico muito desenvolvido. Enquanto todos pensavam que estava participando, vivia em fantasias, mas se tornava imediatamente presente se solicitada, de forma que ninguém soubesse disso. Isso fica com o nome institucional de teatro particular de sua vida mental; era tão mais importante e perigoso, já que a direção tutelada de sua atividade nada oferecia, e não havia nenhuma vivência de sua vida se movendo para dar conteúdo à sua atividade mental." 
Aqui Breuer já mostra importantes percepções da gênese da doença. Continuando, sobre a personalidade da paciente:

"Vontade enérgica, teimosia grande e continuada, que só por bem dá lugar à vontade do outro. A volubilidade que agora a atinge deve ser totalmente patológica.

Boa, viva compaixão; é o impulso nela que desperta mais cedo a ação. $O$ cuidado e a atenção para com alguns doentes the trouxeram... resultados excelentes.

Eu a considero bem autêntica, mesmo que algumas mistificações irrompam, pela sua doença.

Em todo caso, é sempre melhor considerá-la autêntica, ou assim parecer, porque ela nada despreza mais do que a mentira, cada ação sobre ela só é possível apelando para suas boas qualidades." (aqui e no restante do artigo as ênfases são minhas - $J T$ ).

Breuer foi inicialmente procurado pela família por causa da tosse crônica de Bertha. "mas logo percebi que a paciente era doente mental, por causa de seu comportamento peculiar." Com visão aguda, Breuer observou laconicamente "o ambiente ainda não percebeu nada". Ele pensava seguramente na mãe dela, que não era especialmente solidária com a filha.

No decorrer da doença, Anna $\mathrm{O}$ desenvolveu os mais variados sintomas psicossomáticos: graves distúrbios de visão (diminuição do campo visual), distúrbios dos movimentos oculares (estrabismo), paralisia muscular, anestesia nas extremidades inferiores, dores de cabeça aniquilantes. Ao mesmo tempo, Breuer acentuou o aspecto psíquico:

"A observação agora mais atenta mostra o estado psíquico gravemente enfermo, alteração muito rápida e extrema de humor, euforia, mas bem passageira, ou então sentimento de medo, alucinações de medo de cobras pretas, excitações, ... joga almofadas à sua volta, enquanto 
o permite a paralisia dos braços, xinga, arranca seus botões e coisas parecidas. De entremeio, porém, horas claras, em que se queixa da profunda escuridão de sua cabeça, como não conseguiria pensar ... Cada vez parece mais claro que ela teria dois estados de consciência separados... Num ela reconheceu seu ambiente, ficou triste e manhosa, mas relativamente normal, no outro ela alucinou, ficou "malcriada" ... ela notou os lapsos no decorrer de suas apresentações."

À vista de Breuer desenvolviam-se, na seqüência dos diversos acontecimentos no ambiente familiar de Bertha, cada vez mais sintomas, por vezes bizarros, até chegar na chamada afasia, a perda da capacidade de falar:

"Durante o processo foi primeiramente observado que falhavam suas palavras. Gradualmente isso aumentou. Apareceram então as alterações gramaticais típicas dos afásicos. Ela perdeu toda a conjugação de verbos, por fim os falava apenas errados, em geral infinitivos construídos de particípios pretéritos de conjugações fracas, sem sintaxe, sem artigos. No estágio seguinte também falharam quase todas as palavras, ela as procurava cansativamente em 5 ou 6 línguas ao mesmo tempo..."

Por um tempo Bertha não conseguia falar mais nada, ou só falava em inglês, mas não em sua língua materna. Como não iremos nos ocupar dos detalhes do caso como tal, limito-me aos pontos nos quais Breuer ganhou compreensão importante sobre a origem e natureza psíquica dos sintomas e, com ajuda da paciente, descobriu um método para sua superação.

"Observou-se que em suas ausências ela todo dia se movia num determinado circuito de apresentação... De tarde ela ficava sonolenta, e à noite se queixava 'doer, doer'. Primeiro casualmente, depois quando se aprendeu a prestar atenção, de propósito, irrompia então das outras uma palavra que tinha a ver com aquela apresentação e, assim que ela passava para o 'outro lado', começava... a contar uma história do tipo 
como no livro ilustrado de Andersen ou de contos de fada, e ao final dessa história ela falava bem corretamente. Momentos depois do final, ela acordava, ficava visivelmente acalmada, ou como ela dizia, 'comportada'. (...) As histórias eram todas trágicas, por vezes muito belas, em geral giravam em torno da situação de uma moça amedrontada, sentada e com uma doença, mas também outras diversas. Se de noite eu não arrancasse dela uma história, então deixava de ter a calmaria noturna e na noite seguinte eram duas para contar."

Aqui se encontram as primeiras indicações do que mais tarde Bertha Pappenheim chamou de "talking cure" ("cura pela fala") e o que constituiu o início do método da psicanálise:

"De tudo ficou claro que cada produto de sua atividade doentia, seja produto espontâneo de sua fantasia, seja um resultado obtido da parte doentia de sua psique, funcionava como estímulo psíquico e se desenvolvia, até ser relatado, com isso, porém, também a eficácia era totalmente afetada."

Após os primeiros sucessos terapêuticos com a "remoção" de tais "produtos mentais" pesados, Breuer estava cada vez mais na pista do significado de acontecimentos específicos na vida da paciente, ligados a fortes emoções (afecções), que mais tarde eram "desviados" da consciência e agiam patogenicamente. Ficou claro que acontecimentos durante o cuidado de seus pais mortamente doentes desempenhavam um papel central.

A seguir Breuer conta alguns episódios que o "encheram de espanto":

"(1) A paciente, quando era acordada de noite e levada à cama, nunca tinha suportado que lhe tirassem as meias; só quando acordava às duas ou três ela fazia isso, ... reclamando da mudança, e que a gente a deixasse com as meias. Uma noite ela me contou uma história verdadeira, ocorrida há tempos, como de noite ela sempre ia 
junto ao pai para escutar... como ela então tinha dormido de meias, então uma vez seu irmão a expulsou, e assim por diante. Logo depois do final (da história - JT) ela começou com um ruído manso, porque ela estava na cama com meias, tirou-as e toda aquela manha da meia acabou para sempre.

(2) Ela se queixava do tormento da sede, mas levando águas aos seus lábios, ela não podia ser persuadida a beber nenhuma gota antes que tivesse indicado o porquê. Finalmente ela contou uma noite como tinha visto beber num copo o pequeno cão de sua companheira, do que teve nojo, e não tinha dito nada para não ser grosseira... por 5 minutos se queixou de sede, bebeu $1 / 2$ garrafa de água e dai em diante a barreira para beber desapareceu.

Da mesma forma, surgiu de repente a paralisia do musculi orbiculares palpebrarum (um músculo da face - JT), quando ela tinha reprimido sua explicação, e desapareceu quando, primeiro laboriosamente e depois com a minha ajuda, o acontecimento foi relatado."

Especialmente impressionante foi a interrupção de um sintoma verdadeiramente psicossomático, uma condição de cegueira avassaladora:

"A amaurose real, que com os testes mais diversos pareceu verdadeira, surgiu também por uma afecção e desapareceu após a narração da circunstância."

Agora Breuer via-se em posição de tratar sistematicamente os sintomas histéricos. Com ajuda adicional da hipnose ele procurou fazer a paciente gradualmente se lembrar das condições específicas nas quais tinham surgido os sintomas:

"Cada sintoma particular desse quadro doentio que se desenvolveu foi examinado de per si; as circunstâncias conjuntas em que surgiu, foram narradas numa sequência invertida... de trás para diante até sua primeira manifestação. Quando isso foi narrado, o sintoma foi interrompido para sempre." 
Assim, Breuer conseguiu as primeiras percepções que tiveram consequências insuspeitadas para toda a ciência da psicologia. Em sua contribuição para os Estudos, Breuer escreve mais sobre a terapia de Bertha Pappenheim, se dedica à questão do surgimento da própria doença e do fenômeno da personalidade dividida. O desenvolvimento posterior da teoria e tratamento da histeria foram dominados por Sigmund Freud, que após um curto período de colaboração com Breuer seguiu seu próprio caminho, do qual resultou o formidável aparato da psicanálise.

Não queremos aqui, porém, nos ocupar da psicologia enquanto tal. Para nós são interessantes as reflexões posteriores de Breuer sobre a relação entre psicologia e fisiologia, entre atividade mental e nervosa, que ainda hoje são incrivelmente atuais para a pesquisa cerebral. Antes, porém, algumas palavras sobre o destino posterior de Bertha Pappenheim.

\section{A verdadeira "Anna O"}

Por diversos motivos, especialmente porque Breuer não queria divulgar a identidade da paciente, a história da doença de "Anna O", que Breuer publicou nos Estudos sobre Histeria, não corresponde inteiramente à história real. Nos Estudos surge a impressão de que "Anna O", depois de terminar a terapia com Breuer, ficou essencialmente curada. Sabemos, porém, em parte por meio das cartas do próprio Breuer, que Bertha Pappenheim foi repetidamente tratada em clínicas dos nervos e só muitos anos depois pôde viver como uma pessoa razoavelmente sadia e capaz de trabalhar. Esse atraso se deve muito seguramente aos resquícios e sequelas duradouras de sua doença. Ela se tornou dependente de morfina e do sonífero cloridrato - o que então em casos semelhantes não era incomum e precisou primeiro sair penosamente dessa dependência. Da correspondência se depreende que Breuer, após o final de sua terapia, continuou a se preocupar com ela e que concluiu estar a perspectiva de uma cura definitiva principalmente em sua incomum força de vontade. 
A percepção clara de Breuer sobre o papel decisivo da personalidade, do ser humano individual, para o sucesso de um processo de cura era mais do que simples expressão de sua experiência e ética médica. Toda sua filosofia de vida e concepção do homem se concentravam no que ele ligava à palavra do grego antigo tyké - portanto destino, mas também acaso. Não é fácil e levaria muito longe captar em palavras o conceito disso para Breuer. Deixo aqui por isso apenas uma citação dele mesmo, de uma carta para o filósofo Franz Brentano, de abril de 1903:

"[Meu pensamento] está condicionado por tudo que eu chamei em última análise de tyké [destino] (palavra de raiz órfica para Goethe), educação, meio, leituras, profissão, vivência... Mas de fato isto quer dizer que essa condicionalidade não existe só no meu pensamento, mas é um destino geral; não só dos pequenos pensadores, mas também dos grandes filósofos. E não somente no sentido de que qualquer um, assim como o trabalho de qualquer um, dependa disso, de qual estágio do desenvolvimento da ciência tenha sido alcançado em seu tempo, mas dependia, era influenciado exatamente pelo que eu chamo de tyké..."

A história da cura de Bertha Pappenheim leva muito a pensar no destino. Infelizmente não sabemos quase nada sobre o período entre o final do tratamento por Breuer (provavelmente no fim de 1881) e 1888, quando o primeiro livro de Bertha, Pequenas Histórias para Crianças, foi publicado anonimamente e ela, aparentemente muito bem restabelecida, se mudou para Frankfurt. Tampouco foi possível à autora da interessante e mais recente biografia de Bertha Pappenheim, Marianne Brentzel, preencher essa lacuna em sua história da cura. Parecem-nos muito prováveis as seguintes afirmações:

- Que o tratamento por Breuer acarretou mudança decisiva em seu histórico doentio, o que acabou possibilitando uma cura;

- Que Bertha Pappenheim depois se curou principalmente devido à sua própria força de caráter, o que está inseparavelmente 
ligado ao seu papel posterior como autora, feminista e lutadora pela dignidade e direitos de todas as pessoas;

- Que o exercício intenso de suas forças intelectuais e morais em atividades literárias e beneficentes desempenharam um papel decisivo em sua cura.

De fato, Bertha Pappenheim se tornou uma das mais luminosas manifestações da vanguarda judia de seu tempo. Para possibilitar ao leitor uma impressão de seu caráter, cito aqui uma de suas poesias mais conhecidas (publicada em 1910):

Ai de vós, ó grandes

de vozes tronitroantes!

Cegos sois e surdos,

por mãos sujas comandados.

Não ouvis as vozes da ira,

não vedes a careta da miséria,

não sentis o lamento do povo,

o coração que bate ainda espera

em vós salvação achar.

Deixai que vos diga,

como é desprezível,

a ira desse povo

fazer de apoio

para vossos pés.

A ira do povo é grande,

mas ainda maior é sua força

e a força do sagrado nascimento

e crescimento da liberdade

pela vontade moral

do próprio povo. 
As mãos sujas apodrecem, as vozes altas esmorecem.

Adubado por rios de lágrimas

brotará do solo

de raízes antigas

um novo fruto -

apesar de vós.

\section{O inconsciente e a relação entre cérebro e mente - de Leibniz a}

\section{Breuer}

Josef Breuer foi muito modesto em relação a seus feitos na psicologia. Em uma carta ao pesquisador francês August Forel, escreveu:

"Meu feito consistiu essencialmente em reconhecer o que o acaso me mostrou, ao trabalhar num caso muito elucidativo, cientificamente importante, no qual perseverei com observação atenciosa e fiel e do qual não perturbei a simples compreensão dos dados com preconceitos. Assim pude então muito aprender; muito, cientificamente valioso; mas também importante praticamente, e que para um 'clínico geral' seria impossível tratar de um caso assim, sem que sua atividade e modo de vida fossem com isso completamente abalados. $\mathrm{Na}$ época me congratulei, por não trilhar um tal martírio."

Breuer indica aqui que a cura de doentes psíquicos exige uma intensidade totalmente diferente na relação entre paciente e médico, que pode durar meses e anos, comparada com a da prática médica normal. Ele pagou suas percepções com o preço de um engajamento pessoal terrível, bem como com uma afetação séria de sua paz matrimonial. Em todo caso, parece que Breuer não se ocupou mais do tratamento de doenças psíquicas, exceto por uns poucos outros casos. Mesmo assim, ele continuou a refletir intensivamente nas questões fundamentais da psicologia dos nervos e da pesquisa cerebral. 
Muito mais do que Freud, Breuer acentuou sempre as fronteiras do próprio conhecimento e a necessidade de novas descobertas fundamentais na região fronteiriça entre a psicologia e a fisiologia. Em sua parte dos Estudos de 1895 ("Teoria"), escreveu:

"Mas como estamos hoje ainda longe da possibilidade de uma tal compreensão completa da histeria! Com que traços inseguros são aqui os contornos desenhados, com que toscas hipóteses as lacunas abertas são mais cobertas do que preenchidas. Só uma ponderação acalma um pouco: que esse horror marca e precisa marcar todas representações de processos psicológicos complicados. Para eles vale sempre o que Teseu fala da tragédia em Sonho de uma noite de verão: 'Até o melhor dessa arte é apenas um jogo de sombras.' E até o pior não é sem valor, quando procura, com exatidão e modéstia, estabelecer os contornos das sombras que os objetos reais desconhecidos lançam na parede. Pois é sempre justificada a esperança de que surja alguma parcela de correção e semelhança entre os processos reais e nossa representação deles."

A referência à famosa "imagem da caverna" de Platão é aqui especialmente apropriada, porque as próprias descobertas de Breuer afastaram as dúvidas sobre a realidade do chamado "inconsciente", que há muito levava na psicologia uma existência na sombra e que ainda hoje é muito mistificado. $\mathrm{Na}$ camada mais profunda não é possível alcançar uma compreensão científica da relação entre processos da mente e do cérebro sem um esclarecimento maior desse "inconsciente".

Com sua paciente Bertha Pappenheim, Breuer fez a espantosa descoberta de que os sintomas histéricos - inclusive os aparentemente corporais - são de naturez̧a ideogênica. Eles têm relação com certas representações e ideias, geralmente - como Breuer conseguiu expor em detalhe - com lembranças traumáticas específicas, que estão ligadas a fortes afecções, e que curiosamente jaziam completamente desaparecidos do consciente do paciente, mas que por via dos sintomas "corporais", de certa forma "escapavam". Já se tinha antes suposto que os homens poderiam 
adoecer "de lembranças". Como pode alguém ficar sob o domínio de uma lembrança intensa, sem se lembrar dela?

Breuer precisou de uma crença incomumente forte na regularidade sem lacunas dos processos fisiológicos, bem como dos mentais, para não derrubar prematuramente seu processo de pensamento. A conclusão paradoxal se impôs, contudo, de que há complexos inteiros de pensamentos e lembranças, que continuamente atuam "no segundo plano" da vida mental, que "se contrabalançam" nas vivências e pensamentos da vida e que influenciam as motivações, ações, reações e sentimentos vividos pelo homem a cada momento.

O plano de fundo e a importância da ruptura de Breuer só se tornam então completamente claros quando nos recordamos da longa luta científica com a natureza do "inconsciente", que remonta a Gottfried Wilhelm Leibniz. Para poder melhor valorizar as contribuições próprias de Breuer sobre a relação entre psicologia e fisiologia, e o papel do inconsciente, citamos primeiramente três dos seus predecessores: o próprio Leibniz, Gustav Fechner e o professor de Breuer, Ewald Hering.

\section{Leibniz}

Em seus Novos ensaios sobre o entendimento bumano, escritos em 1704, Leibniz já fala de uma atividade inconsciente permanente da mente:

"Há mesmo muitos sinais dos quais devemos concluir que há em nós a cada instante uma quantidade infinita de percepções, que não são, porém, acompanhadas de consciência e reflexão, mas tão somente representam alterações na mente, das quais não ficamos conscientes... As impressões que se passam na mente e no corpo, quando perdem o estímulo da novidade, não são suficientemente fortes para atrair nossa atenção e memória, que são exigidas por objetos mais sólidos ... Essas percepções desapercebidas são também aquelas que designam e constituem o que nós chamamos um e o mesmo indivíduo: pois sua força conserva no indivíduo traços de suas condições passadas, por meio das quais a conexão 
com seu estado atual é produzido... Por meio das percepções desapercebidas refiro também aquela maravilhosa e prévia harmonia da mente e do corpo... As percepções desapercebidas são, em uma palavra, de importância ainda maior na teoria do espírito do que os corpos desapercebidos na física; e é igualmente irracional se desfazer tanto de uns como de outros sob o pretexto de que caem para fora do domínio de nossos sentidos."

Num outro lugar do diálogo, Teófilo (Leibniz) responde uma pergunta do interlocutor Filaleto (que representa a maneira de pensar de John Locke):

"Filaleto: A afirmação 'a mente sempre pensa', não é porém evidente por si mesma.

Teófilo: Eu tampouco digo isto. Isso exige, para ser determinado, alguma atenção e reflexão. O homem comum tem tão pouca consciência de si quanto da pressão do ar ou da forma esférica da Terra..."

A comparação de Leibniz aplica-se melhor ainda porque ambos os fenômenos - a pressão do ar e a forma esférica da Terra - determinam todas nossas condições de vida, sem serem objetos diretamente de nossa percepção (e geralmente tampouco de nossa consciência). Em outro lugar, Leibniz fala, quase 200 anos antes de Breuer e Freud, com muita precisão sobre o importante papel da "memória inconsciente":

"É certo que infinitamente muitos pensamentos nossos retornam, dos quais tínhamo-nos inteiramente esquecido de que os tivéramos. Já aconteceu de alguém acreditar ter feito um novo poema, para depois se demonstrar que ele o tinha lido palavra por palavra em algum poeta antigo. Muitas vezes compreendemos muitas coisas de forma incomumente fácil, porque no passado, sem que nos lembremos disso, já as tínhamos entendido. [...] Acredito que dessa forma antigos pensamentos retornam frequentemente em sonho." 
Leibniz enfatiza sempre sua concepção de que a mente e o corpo estariam unidos da forma mais estreita e em todos os detalhes: Nada se passa na mente sem que uma alteração material correspondente ocorra, nenhum processo material se passa sem alteraçoes correspondentes na mente. A isto Leibniz ainda acrescenta algo que, a meu ver, é muito raramente compreendido. Como exemplo, eis uma citação de sua carta para a rainha Sofia Carlota da Prússia, do ano de 1702:

"... essas mentes não devem ser algo fora da matéria, mas só algo mais do que ela."

\section{Fechner}

Um século e meio mais tarde, no ano de 1860, Gustav Fechner escreveu seu livro que marcou a época, Elementos de psicofísica. Fechner tinha muita consideração por Leibniz, em toda sua obra refere-se sempre a ele. Seu ponto de vista "monista", que, porém, se afasta de Leibniz em alguns pontos importantes, exerceu uma influência frutífera sobre todo o desenvolvimento posterior da fisiologia, psicologia e pesquisa cerebral. Seguem-se algumas palavras muito úteis sobre como se pode entender a relação entre espírito e cérebro, mente e corpo:

"E qual pode ser a razão dessa relação peculiar, de que podemos observar corpo e mente cada um de per si, mas nunca ambos como sendo imediatamente da mesma natureza ou também imediatamente observáveis em conjunto; pelo contrário, aquilo que é imediatamente da mesma natureza observaríamos mais facilmente de forma imediata em conjunto? [...]

Isto se deixa entrever aqui e ali, por ex. quando alguém fica dentro de um círculo (ou também de uma semiesfera - JT), então o lado convexo do mesmo fica para ele inteiramente oculto sob a linha; quando ele fica fora, é ao contrário, o lado côncavo sob a linha convexa. Ambos lados são, porém, inseparavelmente da mesma natureza, como o lado mental e o corporal do homem, e estes se deixam comparavelmente perceber também como lado interno e externo; é, contudo, igualmente impossível, de um ponto da 
superfície do círculo observar ambos lados do círculo simultaneamente, bem como esses dois lados do homem de um ponto na região da existência humana. Só quando trocamos o ponto de vista, muda o lado do círculo que olhamos, que se esconde por detrás do observado...

O mundo todo consiste em tais exemplos, que nos mostram quando numa coisa há o Um, que de dois pontos de vista surge como duplo, e não podemos ter de um ponto de vista o mesmo que do outro...

O que te parece, do ponto de vista interno, como tua mente, que tu és mesmo essa mente, parece em contraposição do ponto de vista externo como o envólucro corpóreo dessa mente. Há uma diferença, se a gente pensa com o cérebro, ou se observa dentro do cérebro de quem pensa. Então parece muito diferente; mas o ponto de vista é também muito diferente, lá interno, aqui externo; até indizivelmente diferente dos exemplos anteriores e, portanto, até indizivelmente maior a diferença dos modos do fenômeno ...

A ciência natural se coloca de forma consequente para considerar a coisa no ponto de vista externo, a ciência da mente no interno; as visões da vida se apoiam na troca dos pontos de vista, a filosofia natural sobre a identidade do que aparece duplamente, do duplo ponto de vista; uma teoria das relações entre mente e corpo terá de perseguir as relações de ambos os modos do fenômeno do Um.

A psicofísica é uma teoria que tem de se apoiar sobre esses pontos de vista... Por psicofísica deve ser aqui entendida uma teoria exata das relações funcionais ou de dependência entre corpo e alma, mais generalizadamente entre corpóreo e mental, mundo físico e psíquico...

Enquanto houver uma relação funcional entre corpo e alma, nada impediria que a mesma fosse olhada e seguida tanto numa quanto noutra direção, o que se pode explicar adequadamente através da relação funcional matemática que surge entre as variáveis $x$ e $y$ duma 
equação, em que cada variável pode ser arbitrariamente vista como função da outra, e a mesma em suas alterações é dependente de si ..."

\section{Hering}

O aluno de Fechner, Ewald Hering, expande o conceito duma relação funcional reversível entre atividade mental e nervosa em sua famosa conferência "Sobre a memória como uma função geral da matéria organizada" (1870):

"Enquanto o fisiólogo for apenas físico - e uso aqui a palavra física em sua acepção mais ampla - ele se opõe ao mundo orgânico do ponto de vista bem singular, embora puxado para o mais externo... Desse ponto de vista, para o fisiólogo o animal, o homem, não passa de um pedaço de matéria. Que o animal sinta prazer e dor, que se juntem no destino material da forma humana as alegrias e dores de uma mente e a vida mental ativa duma consciência; isso não pode tornar para o físico o corpo animal e humano algo diferente do que ele é: um complexo de substâncias, submetidas às leis que não se curvam a nada, que também seguem a massa da rocha, a substância da planta, um complexo de substâncias cujos movimentos externos e internos interdependem entre si causalmente e de seu meio, tão fortemente quanto a marcha da máquina da movimentação de suas rodas.

E nem sensação nem imaginação, e nem vontade consciente podem formar um elo nessa cadeia de processos materiais que compõem a vida física de um organismo. Se uma questão me for endereçada, e aqui já dou a resposta, então o processo material que as fibras nervosas conduzem do órgão auditivo até o cérebro, precisa enquanto processo material perpassar por meu cérebro para atingir os nervos que movimentam o aparato da fala; ele não pode, ao chegar a um determinado ponto do cérebro, irromper de repente em algo imaterial, para depois de um tempo ou em outro lugar do 
cérebro novamente ocasionar um processo material. Igualmente poderia a caravana entrar no oásis, que lhe reflete a miragem, para depois de passar por um descanso e se refrescar, novamente se lançar no deserto real..."

Aqui Hering remonta à concepção dualista de Descartes, segundo a qual a mente por um lado é pensada como imaterial ("do mundo externo"), e do outro lado estaria em posição de tomar os processos materiais e mudar sua direção. Ele continua:

"Desse modo, o fisiólogo enquanto físico. Mas ele fica atrás do palco, e enquanto pesquisa com esforço os mecanismos do maquinário e observa a ação profissional dos atores por trás dos bastidores, perde o sentido do todo, que o espectador à frente compreende com pouco esforço. O fisiólogo não deveria talvez ao menos por uma vez trocar seu ponto de vista?

É claro que ele não conseguiu ver representado um mundo imaginado, mas ele procura o real. Porém não poderia ser-lhe exigido o conhecimento de todo o aparato dramático e de seus movimentos, se ele o observasse também do outro lado ou ao menos se deixasse escutar o que outros observadores capazes tivessem visto de lá?

A resposta não pode ser dúbia e por isso a psicologia é uma ciência auxiliar indispensável da fisiologia. Se esta até agora conseguiu fazer tão pouco uso da ajuda, então foi sua culpa só em uma mínima parte; pois a psicologia começou tarde a trabalhar seu campo frutífero com o arado do método indutivo, e o solo cultivado só pode fornecer os frutos demandados pelo fisiólogo.

Se agora, portanto, o fisiólogo nervoso está colocado entre o físico e o psicólogo, e se coloca primeiramente com direito à continuidade causal ininterrupta de todos processos materiais como fundamento de sua pesquisa, por outro lado o psicólogo ponderado busca de acordo com o método indutivo as leis da vida consciente, e com isso 
de toda forma faz a hipótese de uma regularidade inabalável como ponto de partida de suas reflexões, e se finalmente o fisiólogo aprende com o mínimo de auto-observação que sua vida consciente depende do destino de seu corpo, e que reciprocamente seu corpo está submisso, dentro de certos limites, à sua vontade: então só lhe resta aceitar que essa dependência mútua entre o mental e o material é igualmente uma lei, e está descoberta a ligação que une para ele a ciência da matéria com a ciência da consciência numa grande totalidade.

Assim considerados, os fenômenos da consciência surgem como funções das transformações materiais da substância organizada, e para não deixar margem a qualquer incompreensão, seja enfatizado, embora se situe no próprio conceito de função - que assim considerados, surgem vice-versa os processos materiais da substância cerebral como funções dos fenômenos da consciência. Pois quando duas variáveis em suas transformações de acordo com certas leis dependem uma da outra, de forma que com a transformação de uma simultaneamente ocorre uma transformação da outra, e vice-versa, então se diz que uma é reconhecidamente função da outra.

Com isso não se pode dizer menos que ambas variáveis mencionadas, matéria e consciência, estão entre si relacionadas como causa e efeito, motivo e consequência; porque sobre elas nada sabemos. E se o materialista considera a consciência como um resultado da matéria, e o idealista ao contrário, a matéria como resultado da consciência, um terceiro finalmente assevera a identidade de mente e matéria; assim o fisiólogo como tal não se ocupa mais disso."

\section{Breuer}

Demos uma breve passada por alguns pensadores, a quem Breuer agradeceu por seu tyké científico. Leiamos agora o próprio Breuer, como ele introduz seu segundo ensaio dos Estudos sobre histeria sob o título de "Teoria": 
"Nesses debates via-se falar pouco do cérebro e absolutamente nada das moléculas. Processos psíquicos devem ser tratados na linguagem da psicologia, de fato não pode se passar diferentemente. Se quiséssemos ao invés de 'imaginação', dizer 'excitação do córtex', então a última expressão teria assim para nós o sentido apenas de quando reconhecemos um velho conhecido numa fantasia e restituímos de volta silenciosamente a 'imaginação'. Pois enquanto nas imaginações os objetos de nossa experiência e nós somos continuamente bem conhecidos em todas suas nuances, 'excitação do córtex’ é para nós mais um postulado, um objeto de conhecimento futuro, esperado. Cada substituto terminológico parece uma mascarada sem sentido."

A polêmica de Breuer poderia ter sido uma advertência para, entre outros, Sigmund Freud. Este alimentava, já durante a cooperação deles, um plano ambicioso para uma psicologia teórica bem abrangente, com a qual tudo devia ser reconduzido a poucos axiomas básicos sobre os modos de funcionamento dos neurônios. Como já mencionado, o Esboço de uma psicologia de Freud foi escrito no mesmo ano no qual foram publicados os Estudos de Breuer. É certo que Breuer estava em completo desacordo com esse Esboço. Principalmente, Breuer estava extremamente cético quanto àquela teoria que expandia o conhecimento da época bem para além de limites razoáveis por meio de extrapolações especulativas e se arrogava a intenção de "explicar tudo". Eis um exemplo, da já mencionada carta para Franz Brentano:

"Eu mantenho ainda que para mim as generalizações mais amplas da ciência não estão muito mais perto, p. ex. do que a morte por calor ou por frio, de que se deduz a segunda lei da teoria do calor. (Tratase aqui da afirmação de que o universo estaria condenado à morte por meio de um aumento contínuo da entropia, devido às leis da termodinâmica - JT). Já observei uma vez que recebo essas afirmações apenas com o benefício da dúvida. Com isso não quero dizer que postule: não existe morte por frio; mas simplesmente que uma frase dessas, estendida a tudo que existe e se move só pode ser 
possível sob a condição tácita de que nosso conhecimento das conversões de energia não deve estar somente correto, mas também completo. Ele é, porém, de antes de ontem."

Este e outros aspectos de seu tyké levaram Breuer a pontos de vista sobre algumas questões fundamentais da biologia que, a seu ver e de suas descobertas, eram decisivas para a relação entre as atividades dos nervos e da mente. Em primeiro lugar ele compartilhava com Ewald Hering a convicção de que a ciência natural não poderia dispensar os conceitos de finalidade, de sentido, no estudo dos organismos vivos. Breuer expressou sua visão bem diferenciada sobre isso numa conferência que despertou interesse, "A crise do darwinismo e a teleologia", na qual afirmava, entre outros:

"Na época em que houve o surgimento e vitória da teoria da seleção, havia entre os naturalistas uma negação bem disseminada e apaixonada da teleologia e ... contra todas as considerações de finalidade. Observações sábias e tolas, piadas boas e ruins eram espalhadas contra a teleologia, mas acima de tudo era boicotada qualquer 'finalidade'. Um órgão não tinha mais nenhuma finalidade, mas sim uma eficiência, etc. Desta atmosfera resultou uma situação de escrúpulo tragicômico. A ciência, aqui no caso principalmente a fisiologia, nunca se livrou dos pensamentos de finalidade, que ela publicamente negava; pois ela é intimamente teleológica ..., pode ignorar a utilidade da eficiência, a finalidade dos órgãos tão pouco quanto a tecnologia pode ignorar a finalidade da máquina. Que todo órgão seja finalista e útil é a hipótese heurística de qualquer pesquisa fisiológica. Desse modo se desenvolveu entre a pesquisa e a teleologia algo como a relação nos versos de Heine: 'Secretamente em casa bebem o vinho, em público pregam a água'. "

Em segundo lugar Breuer era um vitalista esclarecido, no sentido de que não estava disposto a negar ou ignorar as propriedades e características demonstradas dos processos vivos, só porque não se encaixavam nas 
representações físico-mecanicistas da moda. Assim escreveu para seu amigo, o famoso filólogo e filósofo Theodor Gomperz em 25 de julho de 1895:

"Quero dizer que a escola fisicalista não pesquisou mais a essência da vida do que Colombo a costa do Japão; mas como este, ela alcançou e conquistou no esforço para tal algo muito consequente, importante. Essa decepção das esperanças em relação ao problemachave não é, portanto, nenhuma infelicidade, mas ricamente recompensada e precisa ser reconhecida. Schwann acreditou poder definir a célula de forma tão simples quanto uma bolhinha com membrana, núcleo e um interior líquido contendo proteína, e hoje nos convencemos de que os organismos 'elementares' na verdade já se comportam tão autonomamente quanto animais inteiros complexos, que cada célula deve possuir uma estrutura tão complicada, que a ulterior complexificação da organização de animais multicelulares nem explica tanto, então nos encontramos mesmo fortemente desiludidos. - Se nos convencermos de que a análise físico-química apenas tomou as paliçadas do orgânico, mas a fortaleza em si não foi tocada, então duvidamos da correção da afirmativa de que seria apenas uma questão de tempo para dominar o problema-chave também por meio da física e química."

Finalmente, Breuer era um monista convicto. Assim, escreveu na citada carta para Brentano:

"Cada solução dualista do problema antropológico me é inaceitável, porque vivencio diariamente e a cada hora quão inteira é toda função psíquica das condições do córtex cerebral. Estou completamente pronto a seguir as bases que a psique permite manter para o real e o córtex cerebral para o fenômeno; mas que sejam dois, é-me impossivel aceitar." 


\section{A "teoria" de Breuer: sobre a relação entre processos fisiológicos e psicológicos}

Agora chegamos finalmente às próprias reflexões de Breuer sobre o fenômeno da histeria e sua ligação com a fisiologia do sistema nervoso. Mais ainda do que a famosa história da doença de "Anna O", é preciso considerar o ensaio de Breuer "Teoria" nos Estudos sobre histeria como uma pequena obra-prima da exposição dos recentes novos conhecimentos. $\mathrm{Na}$ leitura de sua exposição não se pode naturalmente esquecer que ela foi escrita há mais de cem anos, no começo de um poderoso desenvolvimento da neurologia, assim como da psicologia clínica. O que nos interessa principalmente é a forma pela qual Breuer se move em ambos os mundos ao mesmo tempo - como ele chegou, partindo de sua visão monista, a compreensões que ainda hoje são atuais.

Inicialmente, Breuer fala das formas variadas de "excitação" do sistema nervoso, que são importantes para a compreensão de processos sadios, bem como dos patológicos:

"Nossa linguagem, o resultado da experiência de muitas gerações, diferencia com maravilhosa sutileza todas as formas e graus de agitação crescente, que ainda são úteis para a atividade mental, porque elas aumentam com igualdade a energia livre de todas funções cerebrais, daquelas outras que the são prejudiciais, porque elas de forma desigual às vezes aumentam as funções psíquicas, às vezes as restringem.

Ela chama as primeiras de estímulo, as segundas de excitação. Uma conversa interessante, chá, café estimulam; uma briga, uma maior dose de álcool a excitam. Ao passo que o estímulo apenas desperta o impulso para a utilização funcional da agitação mental, a excitação procura se descarregar em processos mais ou menos fortes, beirando o patológico ou francamente patológicos. Ela compõe a base psicofísica das afecções, e delas deve-se falar em seguida... 
Não é preciso certamente nenhuma outra fundamentação, de que todos aqueles distúrbios do equilíbrio psíquico que chamamos de afecções agudas, começam com um aumento de agitação ... Mas essa agitação incrementada não pode ser utilizada na atividade psíquica. Todas as afecções fortes prejudicam a associação, o processo da imaginação. Fica-se 'desequilibrado' de raiva ou medo. Só aquele grupo da imaginação que despertou a afecção persiste na consciência com maior intensidade. Assim, a compensação da excitação é impossível por meio de atividade associativa.

Mas as afecções 'ativas', 'estênicas', equilibram o aumento de excitação por meio de descarga motora. O júbilo e os pulos de alegria, o tônus muscular aumentado da raiva, a fala zangada e a ação de represália deixam fluir a excitação em atos de movimentação, a dor psíquica se descarrega nos esforços respiratórios e em atos de secreção, soluços e choro. Que essas reações minimizam e acalmam o estímulo, é coisa da experiência diária. Como já observado, a linguagem expressa isso com os termos 'chorar todas as lágrimas, berrar até o último', etc.; o que é dispendido com isto é a excitação cerebral incrementada...

A ira tem reações correspondentemente adequadas às ocasiões. Sendo elas impossíveis ou sufocadas, então entram substitutos em seu lugar. A fala zangada já é um deles. Mas também outros atos bem sem propósito são substitutos. Quando Bismarck precisou reprimir a excitação irada diante do rei, ele então se aliviou jogando ao chão um vaso valioso. Essa substituição arbitrária de uma ação motora por outra corresponde bem à troca dos reflexos de dor naturais por meio de outras contrações musculares...

Quando, porém, um tal transporte da excitação é totalmente vedado à afecção, então a situação é a mesma tanto na ira quanto no susto e no medo: a excitação intercerebral é fortemente aumentada, mas não é descarregada em ação associativa nem motora. Em pessoas 
normais, o distúrbio é equilibrado pouco a pouco; mas, em muitos, surgem reações anormais..."

A essa reação anormal pertence a formação de sintomas histéricos, como Breuer continua a esclarecer. Mas para produzir essa ligação, Breuer precisa apelar para o domínio do "inconsciente", o que na época - como em parte ainda hoje! - estava ligado à incerteza e confusão conceitual. As seguintes palavras são, entre outras, ainda hoje muito valiosas do ponto de vista pedagógico:

"Se a lembrança do trauma psíquico, como um corpo estranho, muito tempo após sua ocorrência ainda for para funcionar como agente ativo presente, e se, porém, o doente não tem nenhuma consciência disso, então precisamos aceitar que existem e agem idéias inconscientes... Seja-nos permitido adentrar um pouco nessa região difícil e sombria...

Todas ideias que vividamente em nós observamos ou observaríamos, se tivéssemos prestado atenção, chamamos de conscientes. Elas são a cada momento muito poucas; e se fora delas ainda existirem outras atuais, precisaríamos chamá-las de ideias inconscientes. Falar sobre a existência de ideias atuais, mas inconscientes ou subconscientes não parece mais ser necessário. São fatos da vida diária. Quando esqueço de ir a uma consulta médica, sinto um desconforto vívido. Sei por experiência o que significa essa sensação: um esquecimento. Em vão examino minhas lembranças, não acho a causa, até que de repente após horas ela surge na consciência. Mas durante o tempo todo fico inquieto. A ideia dessa consulta está sempre agindo, portanto, sempre presente, porém não na consciência. - Um homem ocupado teve de manhã um aborrecimento. Seu escritório o exige totalmente; durante sua atividade seu pensamento consciente está completamente ocupado e ele não pensa em sua raiva. Mas suas decisões são por ela influenciadas, e ele diz exatamente não quando deveria dizer sim. 
Uma boa parte disso que chamamos de ânimo provém de tal fonte, de ideias que existem e agem sob o peso da inconsciência.

Sim, toda nossa condução de vida é continuamente influenciada por ideias subconscientes... - Toda atividade intuitiva é dirigida por ideias que na maior parte são subconscientes... O que é dirigido contra a existência e ação de "idéias inconscientes" aparece na maior parte como chicanas verbais...

Parece, portanto, não haver nenhum impedimento de princípio para que se reconheçam ideias inconscientes também como causas de fenômenos patológicos."

A partir dessa posição, Breuer considera o processo da formação de sintomas histéricos por meio da "conversão" de excitações fortes.

"Os atos motores nos quais é normalmente descarregada a excitação das afecções, são ordenados, coordenados, mas também podem ser despropositados. A excitação desmesurada pode, porém, ultrapassar os centros de coordenação ou se fragmentar em movimentos elementares... Tais reações afetivas anormais já pertencem à histeria; mas elas também surgem fora dessa doença... deve-se designar de histéricos apenas aqueles fenômenos que surgem não como consequência de uma afecção intensa, objetivamente fundamentada, mas que surgem espontaneamente como sintoma de uma doença. Muitas observações, inclusive as nossas, mostraram que estas se baseiam em recordações, que renovam a afecção...

Nós... apontamos como diferentes graus, p. ex., a afecção da raiva pode ser despertada por causa de um insulto, por meio da lembrança, quando esse insulto foi desforrado ou quando foi engolido em silêncio. Se o reflexo psíquico foi seguido pela contextualização original, então a lembrança desencadeia um quantum de excitação bem menor. Caso contrário, a lembrança força sempre de novo as palavras ofensivas nos lábios, que foram no 
passado reprimidas e que formaram o reflexo psíquico daquele estímulo.

Se a afecção original foi descarregada num 'reflexo anormal' e não num normal, então ela é novamente desencadeada por meio da lembrança; a excitação proveniente da ideia afetiva é 'convertida' num fenômeno corporal (Freud) "

Esses curtos excertos podem bastar para mostrar como pela primeira vez o enigma dos sintomas histéricos foi de certa forma arejado. $\mathrm{O}$ desenvolvimento ulterior da "teoria da conversão", para a qual Freud contribuiu muito, nos levaria longe demais na psicologia para os atuais fins. Queremos apenas, digamos, "dar um mergulho" e, como conclusão, fazer ainda umas considerações, sobre o que a atual pesquisa cerebral pode aprender com o exemplo de Breuer e seus predecessores espirituais.

\section{Considerações finais sobre a pesquisa cerebral}

Se aqui nos ocupamos tanto da psicologia e sua história e pouco com neurônios e impulsos elétricos, foi por causa da mensagem de Ewald Hering: a psicologia é uma ciência auxiliar indispensável da fisiologia. Por quê? Porque ela (para falar como Fechner) pega as atividades do cérebro pelo lado de dentro, "côncavo", que aparecem então como "atividades mentais". A isto pertence não só a compreensão de uma pessoa em suas próprias atividades mentais, mas também a capacidade de "espiar" dentro da atividade mental de outra pessoa, de certa forma.

Essa capacidade de empatia na compreensão, que Breuer possuía em grande parte, forma não somente o fundamento indispensável de qualquer terapia bem sucedida de pessoas psiquicamente doentes, mas ela constitui a base de toda comunicação humana, na medida em que esta realiza o transporte de ideias e imagens, e não apenas uma pura troca de "sinais" no sentido do processamento eletrônico de dados.

Ideias e imagens pertencem (para falar novamente como Fechner) ao lado "côncavo" da mente, elas podem ser vivenciadas apenas "de 
dentro", enquanto um determinado processo mental, que ocorre dentro duma pessoa, é reproduzido por outra pessoa. Somente através desse processo de reprodução a representação recebe um sentido, um conteúdo.

Exatamente essa comunicação de ideias por meio da reprodução dos processos de produção mentais correspondentes é que está no centro da cultura e educação clássicas. A capacidade para isso é exercitada e desenvolvida principalmente pela atividade com música e poesia no sentido clássico, mas também através da atividade com as obras de grandes pensadores, que conseguem comunicar suas ideias verdadeiramente à distância de séculos. Em contrapartida a "informação" no sentido técnico restrito não contém nenhum significado de per si; ela só recebe um sentido através de processos mentais! Essa distinção extremamente importante costuma hoje passar desapercebida, porque se usa "informação" descuidadamente para designar tudo quanto é possível.

As observações precedentes têm hoje implicações do mais alto alcance para a pesquisa cerebral. Muitos pesquisadores cerebrais se deformam por meio de sua fixação exclusiva por analogias com o campo do processamento eletrônico de dados. A pesquisa cerebral é, ela própria, uma atividade mental, ela trabalha com ideias, imagens, conceitos. Como pode o pesquisador cerebral entender a função dum órgão, com cuja ajuda pode ser produzida e compreendida uma riqueza infinita de ideias, quando seu próprio mundo mental fica reduzido a um repertório ridiculamente pequeno de ideias mecanicistas? Apesar de progressos técnicos na pesquisa cerebral, o abismo entre processos mentais de um lado e processos cerebrais de outro se tornou não menor, mas ainda maior, em comparação com Fechner, Hering ou Breuer!

Contra nossa crítica poder-se-ia argumentar: "exatamente como, a partir de dois algarismos 0 e 1 pode-se produzir um domínio infinito de números binários, deveria ser possível reconduzir os modos de funcionamento do cérebro a uma pequena seleção de 'mecanismos neuronais básicos’. A redução a poucos conceitos básicos é a condição necessária para que se possa proceder cientificamente." 
Esse argumento ignora, porém, a diferença fundamental entre informação e ideias. Se formei um número 10011101011, com isso não produzi nenhum sentido. Também é um erro fundamental acreditar que um número ou uma sequência de impulsos elétricos poderia codificar uma ideia ou imagem. Um código é uma transformação matemática entre uma série de símbolos; quando deciframos uma série de símbolos codificados, ficamos apenas com uma outra série de símbolos, mas com nenhuma ideia, nenhum sentido. Agora o paradoxo parece aumentar ao infinito. Se processos neuronais apenas operam em "bytes" e não têm nenhum sentido de per si, como podem as atividades cerebrais e mentais serem afinal colocadas em correspondência umas com as outras?

Os onze pesquisadores cerebrais citados no começo deste ensaio indicaram em seu manifesto uma possível saída, embora de forma algo mutilada. Eles se referem aos "processos fisiológicos verdadeiros" nos neurônios no cérebro e entre eles, e que não seriam abrangidos através dos conceitos atuais da informática e da inteligência artificial. Propõem que "ao lado da neurobiologia experimental seja introduzida a neurobiologia teórica como disciplina de pesquisa, semelhantemente à física teórica, que possui uma grande independência dentro da física."

Até aqui, muito bem. Mas de que ideias e conceitos se serviria uma "neurobiologia teórica"? Dentre outros, a meu ver, ela deveria reconhecer todo o alcance do fato de que cada um dos estimados 30-100 bilhões de neurônios de nosso cérebro representa um elemento vital que, justamente como elemento vital - não simplesmente como "elemento de circuito", interage reciprocamente com todo o ambiente neuronal. Isso exige que, de acordo com Breuer, todos os processos vivos circunscrevam suas essências de acordo com um caráter "teleológico": seu comportamento é concebido por princípio como tendo sentido, como tendo finalidade. Tais expressões acarretam que, para a compreensão das atividades cerebrais em todos os níveis, sejam aduzidos ideias e princípios superiores, e não uma simples combinação de circuitos e mensagens químicas. O que Hering chamou de sentido do todo não pode faltar. 
Exatamente assim pensaram quase todos grandes biólogos do passado, até que a biologia molecular ameaçou a biologia "clássica" com seu apelo exageradamente mecanicista. O trabalho daqueles biólogos resultou na existência na biologia de uma série de ideias e imagens importantes, que têm sua total validação experimental e teórica completamente independente das interpretações da biologia molecular. Nos últimos tempos observa-se de diversos lados esforços para interromper a unilateralidade dos métodos da biologia molecular, e ao mesmo tempo conservar as enormes possibilidades tecnológicas e o conhecimento detalhado alcançado pela biologia molecular.

A fraqueza duma visão estreita das coisas pela biologia molecular se expressa, entre outras, pela falta de uma concepção verdadeiramente sintética da interação (comunicação) entre processos vitais. O conceito de comunicação recai ao invés numa série incompreensível de "mecanismos moleculares" isolados. Essa carência conceitual atua muito desvantajosamente na pesquisa cerebral, onde num certo sentido "tudo" é comunicação.

Podemos formular o ponto central mais ou menos assim: para a compreensão de processos biológicos cerebrais deve-se permitir o aduzir de principios superiores, que se apoiem numa consideração integrada das capacidades mentais do homem. A esse respeito não se pode abstrair da pesquisa cerebral o fenômeno da comunicação metafórica de ideias, como ocorre de forma magnífica nos escritos citados acima de Leibniz, Fechner e Hering. O "mecanismo antimecanicista" de cada transporte de ideias liga-se estreitamente por um lado ao inconsciente, por outro lado ao elemento criativo das atividades mentais.

No plano do cérebro como um todo, isto se liga à recomendação de Hering para estabelecer a psicologia como ciência auxiliar da pesquisa cerebral. Nada nos impede de procurar ideias e princípios superiores, que englobem as funções como processos parciais do cérebro, como p. ex. dos neurônios e grupos de neurônios.

Uma orientação útil nos dá a abordagem de Hering e Breuer na neurologia. Isto compreende a forma aparentemente simplória, mas ao 
mesmo tempo muito compacta de como Breuer usou em sua contribuição aos Estudos os conceitos de "excitação", "impulso", "estímulo", para estabelecer uma ponte entre a atividade nervosa e os processos psíquicos. Aqui a palavra "excitação" contém muito mais do que se entende hoje na teoria dos potenciais de membrana.

O esforço de compreender os modos de funcionamento e a "vida interior" dos subsistemas neuronais do cérebro com a ajuda de ideias e princípios superiores diminuiria a distância conceitual entre atividades mentais e cerebrais. Processos que se podem associar a um conteúdo com sentido não se passam, portanto, apenas no plano do cérebro, como órgão indivisível, indiferenciado.

Com isso não se deve esquecer que os processos parciais, que aqui designamos como "neuronais", são influenciados e modificados de uma forma determinada por meio de sua participação no processo integrado do cérebro. É um grande erro supor que os processos mentais superiores, que estudamos e vivenciamos "de dentro" possam ser reduzidos ao plano puramente combinatório do "processamento da informação". Mais ainda: aqueles processos mentais nos quais se baseia a capacidade das descobertas científicas fundamentais e que se pode chamar de "criativos" não se deixam reduzir a princípios gerais da biologia enquanto tais.

Em nossa opinião é absolutamente um erro procurar "esclarecer" na neurologia a existência da consciência e da razão humana. Pelo contrário, dever-se-ia derivar da existência comprovada desses fenômenos superiores as conclusões necessárias para o funcionamento do cérebro e seus componentes neuronais. Eis uma mensagem essencial do pensamento monista. Pois em geral sempre vale que: o superior se deixa "esclarecer" a partir do inferior só na aparência. Sempre que o superior parece se mostrar a partir do inferior, isto é um sinal de que no inferior entrou uma semente do superior, que deixamos passar despercebido - um "infinitamente pequeno", que por meio de circunstâncias favoráveis foi despertado e se deixou desenvolver por completo. Até mesmo esse "infinitamente pequeno" o reducionismo não quer aceitar, muito menos eliminar. 
Gostaríamos de com isso concluir o percurso de nossas reflexões. Em última instância, o valor moral das atividades científicas está em poder melhorar e enobrecer a vida das pessoas. Se aqui honramos os esforços de Josef Breuer, então não pensemos apenas em suas descobertas científicas como tais, mas muito mais: que ele curou e ajudou muitas pessoas. Dentre estas, Bertha Pappenheim, que dedicou o resto de sua vida a valorizar as pessoas.

\section{Referências Bibliográficas}

BRENTZEL, Marianne: Sigmund Freuds Anna O. - Das Leben der Bertha Pappenheim, Reclam Leipzig 2004

BREUER, Josef: Die Krisis des Darwinismus und die Teleologie. Conferência pronunciada em 2 de maio de 1902. Publicada por Gerd Kimmerle, Archiv der Edition Diskord, 1986

BREUER, Josef: Frl. Anna O... (História da doença), Teoria e (em conjunto com Sigmund Freud) Sobre o mecanismo psíquico de fenômenos histéricos - apresentação preliminar em Estudos sobre histeria, publicado em 1895. Em: Sigmund Freud e Josef Breuer: Studien über Hysterie. Franz Deuticke, Leipzig/Wien. Frankfurt a. M.: Fischer,1991

ELLENBERGER, Henri: Die Entdeckung des Unbewußten. Diogenes, 2005

FREUD, Sigmund: Entwurf einer Psychologie, manuscrito inédito do ano de 1895, disponível na internet: http://www.lutecium.fr/Jacques Lacan/transcriptions/freud esquisse de.pdf

HERING, Ewald: Vier Reden, Über das Gedächtnis als eine allgemeine Funktion der organisierten Materie (Wien, 1870). Über die sperifischen Energieen des Nervensystems (Prag, 1884). Zur Theorie der Vorgänge in der lebendigen Substanz (Prag, 1888). Zur Theorie der Nerventätigkeit (Leipzig, 1899). Amsterdam: E.J. Bonset, 1969

HIRSCHMÜLLER, Albrecht: Physiologie und Psychoanalyse in Leben und Werk Josef Breuers. Verlag Hans Huber, 1978

LEIBNIZ, Gottfried Wilhelm: Neue Abhandlungen über den menschlichen Verstand. Felix Meiner Verlag, 1996

PAPPENHEIM, Bertha: Gebete. Hentrich \& Hentrich, 2003

Manifesto de onze pesquisadores do cérebro (Christian Elger, Angela Friederici, Christof Koch, Heiko Luhmann, Christoph von Malsburg, Randolf Menzel, Hannah Monyer, Frank Rösler, Gerhard Roth, Henning Scheich, Wolf Singer), em Gebirn und Geist, 6/2004, disponível na internet: http://www.gehirn-und-geist.de/artikel/852357\& z=798884 